\author{
Asian Journal of \\ Medical and Biological Research \\ ISSN 2411-4472 (Print) 2412-5571 (Online) \\ www.ebupress.com/journal/ajmbr
}

\title{
Article \\ Implication of some biochemical parameters on normal cyclic and repeat breeding process in Bangladeshi dairy cows
}

\author{
Mohammad Azizur Rahman ${ }^{1 *}$, Anowar Us Sadat ${ }^{1}$, Forhad Uddin ${ }^{1}$, Morshed Alam ${ }^{1}$ and Ahsan Habib ${ }^{2}$ \\ ${ }^{1}$ Department of Biochemistry and Molecular Biology, Jahangirnagar University, Savar, Dhaka 1342, \\ Bangladesh \\ ${ }^{2}$ Bangladesh Livestock Research Institute
}

*Corresponding author: Mohammad Azizur Rahman, Department of Biochemistry and Molecular Biology, Jahangirnagar University, Savar, Dhaka 1342, Bangladesh. E-mail: azizbmb@juniv.edu

Received: 31 May 2020/Accepted: 29 June 2020/ Published: 30 June 2020

\begin{abstract}
Repeat breeding is one the most common reproductive disorders that hinders favorable productivity in domestic animals. Repeat breeding in dairy cows not only affects the fertility of the cattle to a considerable extent but also incurs great economic loss to the farmer. Biochemical profile can indicate the nutritional status and help in diagnosis and management of infertility in animals. Present study explores the implication of some biochemical parameters (total protein, bilirubin and some macro minerals as calcium, inorganic phosphorus and magnesium) on normal cyclic breeding process of Bangladeshi dairy cows. Current observation indicates that the lower calcium, inorganic phosphorus and magnesium concentrations might be associated with the ovulatory disturbances in repeat breeder cows. On the other hand, total protein and bilirubin do not play a significant role in causing repeat breeding problem in those cows. Thus, this study provides supportive evidence about the importance of calcium, inorganic phosphorus and magnesium in the resumption of repeat breeding condition.
\end{abstract}

Keywords: estrus cycle; ovulation; protein; macro minerals; normal cyclic breeding; repeat breeding

\section{Introduction}

Bangladesh possesses 23.90 million heads cattle. Most of them are indigenous type (about 80\%) and some portions of indigenous cattle were crossed with exotic high yielding dairy and beef breeds. In general, the production performances of this cattle population are generally low. But they possess higher genetic biodiversity and popularly known for their higher reproductive efficiency. However, a very small number of cows are yielding 2 to 3 times higher milk than their population average (Austin, 1951). Although dairy is an important source of income for the rural poor, unfortunately the condition of dairy in Bangladesh is not healthy. According to the livestock and poultry survey in 1988-89, there are 20.36 million cows in Bangladesh. These are mainly Bos Indicus (Zebu), which are generally small in size and slow, in growth. They are low in weight and produce comparatively less milk. The density of cattle population is comparatively higher in Bangladesh compared to other neighboring countries. However, there is a problem of low productivity of the cattle in terms of milk and meat production (Ghosh and Maharjan, 2001).

In spite of the huge cattle population in our country, the performance of milk production is far below compared with the same in other developed countries. Reproductive problems are common cause of profit loss to the farmers as far as dairy farming and as well as beef production. The success of the dairy cattle economy lies in proper and optimal reproductive rhythm of each individual cow and buffalo in the herd within normal physiological range (Baghel, 2006). Longer dry period and reduced calving and lactations during the life span of an animal cause heavy economic loss. Infertile animal mean a direct loss in milk production, whereas reduced calf crops hamper the selection efficiency in long-term dairy herd improvement (Dhaliwal 2005).

The breeding efficiency of dairy cows is lowered by a number of reproductive disorders like endometritis, anestrus and repeat breeding resulting in great economic losses to the dairy farmers (Dutta and Baruah, 1988). 
Repeat breeding is one of the major problems affecting the reproductive efficiency. The cause of repeat breeding is multifaceted; most common causes are genitival, anatomical defects of the reproductive tracts hormonal imbalances, infections such as clinical subclinical endometritis and poor management (Saraswat and Purohit, 2016). Normal levels of various biochemical constituents are indispensable for normal function of various systems of the body including the reproductive system. Changes in these constituents have been blamed for reproductive failures (Das and Biswas, 2002; Saraswat and Purohit, 2016). We, therefore, hypothesized, that serum macro mineral concentrations would be decreased in repeat breeder dairy cows compared to dairy cows of normal fertility. Therefore, the present study was undertaken to investigate the serum profile of some biochemical parameters (total protein, bilirubin and some macro minerals as calcium, inorganic phosphorus and magnesium) on normal cyclic (NC) and repeat breeding (RB) cows, so as to compare and define the probable biochemical etiological factors involved in the infertility problem of the farm managed dairy cows of Baghabari milk shed area of Bangladesh.

\section{Materials and Methods \\ 2.1. Study area}

The study was conducted in different places for different purposes. For this study, some activities were performed at cattle farmer's house, some at Bangladesh Livestock Research Institute (BLRI) and some at Department of Biochemistry and Molecular Biology, Faculty of Biological Sciences, Jahangirnagar University (JU), Savar, Dhaka, Bangladesh.

\subsection{Selection of animals, feeding and management}

A total of sixty (60) dairy cows ( $30 \mathrm{NC}$ and $30 \mathrm{RB}$ ) had been selected for the present study. Selected animals were kept under uniform feeding and management condition and fed with green grass/fodder with free access to water. All the cows were examined by mobile ultra sound scanner machine for checking whether the animals were clinically disease free. The selected cows were categorized into two groups. The first group of cows was bred and conceived normally within three artificial inseminations during their estrus cycles which were called normal cyclic (NC) cows. The second group of cows was those animals who did not conceive after three or more artificial inseminations during their estrus cycles which were called repeat breeder (RB) cows.

\subsection{Synchronization of dairy cows}

Poor rates of estrus detection combined with poor conception rates (CR) make management of reproduction in lactating dairy cows a challenge in most dairy herds. To help producers manage reproduction more efficiently, protocols for synchronization of estrus have been developed. Estrus (heat) synchronization in cattle involved manipulating the females' estrus cycle so they could be bred at about the same time. The normal 21-day estrus cycle in cattle can be altered by an effective estrus synchronization protocol. RB cows had been synchronized with the treatment of GnRH and PGF2 $\alpha$. The cows were synchronized using the Ovsynch protocol, followed by PG treatment 7 days later. The GnRH1 and GnRH2 injected on days 0 and 9, respectively, comprised $200 \mu \mathrm{g}$ of gonadorelin acetate. The PG injected on day 7 (PG1) and day 16 (PG2) comprised $500 \mu \mathrm{g}$ of cloprostenol sodium. After the PG2 injection, the cows were under intensive observations for the following 6 days; two persons visually monitored the cows round the clock for mounting activity or other behavioral signs typical of estrus. Starting at $15 \mathrm{~h}$ from estrus onset, the animals were monitored for ovulation time by repeated $6 \mathrm{~h}$-interval examinations by trans-rectal ultrasonography, and ovulation was considered to occur $3 \mathrm{~h}$ before the last examination, when the pre-ovulatory follicle disappeared from the ovary. The diameter of the pre-ovulatory follicle was also recorded at the time of the first ultrasound screening for ovulation.

\subsection{Blood sample collection from selected cows}

A total of sixty (30 NC cows and $30 \mathrm{RB}$ cows) blood samples each from $30 \mathrm{NC}$ cows and $30 \mathrm{RB}$ cows were collected. Blood was drawn from the jugular vein of each cow and kept in sterilized vacutainer mixed with anticoagulant.

\subsection{Preparation of serum and biochemical tests}

Serum samples were prepared in the Animal Health Laboratory of Bangladesh Livestock Research Institute, Regional Station, Baghabari, Sahjadpur, Sirajgonj-6770, Bangladesh through centrifugation $(1500 \times \mathrm{g}$ for 20 $\mathrm{min})$. The separated serum was collected in a sterile vial and preserved at $-20^{\circ} \mathrm{C}$ laboratory deep freezer until analysis. All the biochemical tests were performed using commercially available kits and reagents (Crescent 
Diagnostics, Jeddah, KSA). Analyses were carried out by spectrophotometric measurement (PD-303S spectrophotometer, Japan).

\subsection{Statistical analyses}

Data had been analyzed following one-way analysis of variance (ANOVA) using statistical package for the social science (SPSS) version 16.0 (IBM, IL, USA). Results had been expressed as mean \pm SE $[(P<0.01)$ and $(P<0.001)]$.

\section{Result}

\subsection{Biochemical concentrations in normal and repeat breeding cows before estrus}

Calcium concentrations $(\mathrm{mg} / \mathrm{dl})$ present in serum of normal cyclic (NC) and repeat breeder (RB) cows before estrus has been illustrated in Table 1. Statistical analysis shows that serum calcium concentrations in NC cows were significantly higher $(P<0.01)$ than those of RB cows.

Table 1. Serum biochemical constituents $(M e a n \pm S E)$ in normal cyclic and repeat breeder cows before onset of estrus.

\begin{tabular}{|l|l|l|l|}
\hline $\begin{array}{l}\text { Serum biochemical } \\
\text { parameters }\end{array}$ & $\begin{array}{l}\text { Normal cyclic cows } \\
(\boldsymbol{n}=\mathbf{1 5})\end{array}$ & $\begin{array}{l}\text { Repeat breeder cows } \\
(\boldsymbol{n}=\mathbf{1 5})\end{array}$ & $\boldsymbol{P}$-value \\
\hline Calcium, $\mathrm{Ca}(\mathrm{mg} / \mathrm{dl})$ & $8.71 \pm 0.097$ & $7.99 \pm 0.182$ & $0.009 * *$ \\
\hline Phosphorus, P (mg/dl) & $5.87 \pm 0.115$ & $4.84 \pm 0.194$ & $0.000^{* * *}$ \\
\hline Magnesium, Mg (mg/dl) & $2.42 \pm 0.073$ & $2.06 \pm 0.074$ & $0.006^{* *}$ \\
\hline Total Protein, TP (g/dl) & $8.63 \pm 0.152$ & $8.65 \pm 0.105$ & $0.923^{\mathrm{NS}}$ \\
\hline Bilirubin $(\mathrm{mg} / \mathrm{dl})$ & $0.737 \pm 0.029$ & $0.739 \pm 0.034$ & $0.968^{\mathrm{NS}}$ \\
\hline
\end{tabular}

$\mathrm{P}=$ probability; $\mathrm{n}=$ number of serum specimen; $\mathrm{NS}=$ not significant $(\mathrm{P}>0.05) ; * *=$ significant at $1 \%$ level $(P<0.01) ; * * *=$ significant at $0.1 \%$ level $(P<0.001)$.

Serum phosphorus concentrations $(\mathrm{mg} / \mathrm{dl})$ in normal cyclic $(\mathrm{NC})$ and repeat breeder $(\mathrm{RB})$ cows before estrus was $5.87 \pm 0.115$ and $4.84 \pm 0.194(\mathrm{mg} / \mathrm{dl})$, respectively (Table 1$)$. Statistical analysis shows that serum phosphorus and magnesium was significantly higher $(P<0.001)(2.42 \pm 0.073 \mathrm{mg} / \mathrm{dl})$ in normal cyclic cows than repeat breeder cows $(2.06 \pm 0.074 \mathrm{mg} / \mathrm{dl})$. However, no statistical difference of serum protein and bilirubin concentrations between $\mathrm{NC}$ and $\mathrm{RB}$ cows were observed before standing heat (Table 1).

\subsection{Biochemical concentrations in normal and repeat breeding cows after estrus}

Table 2. Serum biochemical constituents $(M e a n \pm S E)$ in normal cyclic and repeat breeder cows after onset of estrus.

\begin{tabular}{|l|l|l|l|}
\hline Serum biochemical parameters & $\begin{array}{l}\text { Normal cyclic cows } \\
(\boldsymbol{n}=\mathbf{1 5})\end{array}$ & $\begin{array}{l}\text { Repeat breeder cows } \\
(\boldsymbol{n}=\mathbf{1 5})\end{array}$ & $\boldsymbol{P}$-value \\
\hline Calcium, $\mathrm{Ca}(\mathrm{mg} / \mathrm{dl})$ & $8.50 \pm 0.063$ & $7.61 \pm 0.140$ & $0.000^{* * *}$ \\
\hline Phosphorus, $\mathrm{P}(\mathrm{mg} / \mathrm{dl})$ & $5.52 \pm 0.113$ & $4.43 \pm 0.254$ & $0.003^{* *}$ \\
\hline Magnesium, Mg $(\mathrm{mg} / \mathrm{dl})$ & $2.32 \pm 0.096$ & $2.00 \pm 0.024$ & $0.006^{* *}$ \\
\hline Total Protein, $\mathrm{TP}(\mathrm{g} / \mathrm{dl})$ & $7.88 \pm 0.162$ & $8.21 \pm 0.112$ & $0.108^{\mathrm{NS}}$ \\
\hline Bilirubin $(\mathrm{mg} / \mathrm{dl})$ & $0.630 \pm 0.021$ & $0.707 \pm 0.042$ & $0.167^{\mathrm{NS}}$ \\
\hline
\end{tabular}

$\mathrm{P}=$ probability; $\mathrm{n}=$ number of serum specimen; $\mathrm{NS}=$ not significant $(\mathrm{P}>0.05) ; * *=$ significant at $1 \%$ level $(P<0.01) ; * * *=$ significant at $0.1 \%$ level $(P<0.001)$.

Table 2 illustrates that serum calcium, magnesium and phosphorus concentrations (mg/dl) in NC and RB cows after estrus differed significantly $(P<0.001)$. However, no significant change was observed in case of serum total protein and bilirubin concentrations. 
3.3. Biochemical concentrations in $\mathrm{NC}$ and $\mathrm{RB}$ cows before and after standing estrus

There was no significant $(\mathrm{P}>0.05)$ variation of serum calcium, magnesium and phosphorus concentrations between "before standing estrus" and "after standing estrus" in NC and RB cows (Table 3 and 4). However, significant variation was observed in case of bilirubin and protein concentrations in NC cows (Table 3) and only in protein concentration of RB cows (Table 4).

Table 3. Serum biochemical constituents $(M e a n \pm S E)$ in normal cyclic cows before and after standing estrus.

\begin{tabular}{|l|l|l|l|}
\hline Serum biochemical parameters & $\begin{array}{l}\text { Normal cyclic cows } \\
\text { before standing estrus } \\
(\boldsymbol{n}=\mathbf{1 5})\end{array}$ & $\begin{array}{l}\text { Normal cyclic cows } \\
\text { after standing estrus } \\
(\boldsymbol{n}=\mathbf{1 5})\end{array}$ & $\boldsymbol{P}$-value \\
\hline Calcium, $\mathrm{Ca}(\mathrm{mg} / \mathrm{dl})$ & $8.71 \pm 0.097$ & $8.50 \pm 0.063$ & $0.099^{\mathrm{NS}}$ \\
\hline Phosphorous, $\mathrm{P}(\mathrm{mg} / \mathrm{dl})$ & $5.87 \pm 0.115$ & $5.52 \pm 0.113$ & $0.095^{\mathrm{NS}}$ \\
\hline Magnesium, Mg $(\mathrm{mg} / \mathrm{dl})$ & $2.42 \pm 0.073$ & $2.32 \pm 0.096$ & $0.215^{\mathrm{NS}}$ \\
\hline Total Protein, $\mathrm{TP}(\mathrm{g} / \mathrm{dl})$ & $8.63 \pm 0.152$ & $7.88 \pm 0.162$ & $0.003^{* *}$ \\
\hline Bilirubin $(\mathrm{mg} / \mathrm{dl})$ & $0.737 \pm 0.029$ & $0.630 \pm 0.021$ & $0.003^{* *}$ \\
\hline
\end{tabular}

$\mathrm{P}=$ probability; $\mathrm{n}=$ number of serum specimen; $\mathrm{NS}=$ not significant $(P>0.05) ; * *=$ significant at $1 \%$ level $(P<0.01)$.

Table 4. Serum biochemical constituents $(\mathrm{Mean} \pm \mathrm{SE})$ in repeat breeder cows before and after standing estrus.

\begin{tabular}{|l|l|l|l|}
\hline $\begin{array}{l}\text { Serum biochemical } \\
\text { parameters }\end{array}$ & $\begin{array}{l}\text { Repeat breeder cows before } \\
\text { standing estrus } \\
(\boldsymbol{n}=15)\end{array}$ & $\begin{array}{l}\text { Repeat breeder cows } \\
\text { after standing estrus } \\
(\boldsymbol{n}=\mathbf{1 5})\end{array}$ & $\boldsymbol{P}$-value \\
\hline Calcium, $\mathrm{Ca}(\mathrm{mg} / \mathrm{dl})$ & $7.99 \pm 0.182$ & $7.61 \pm 0.140$ & $0.099^{\mathrm{NS}}$ \\
\hline Phosphorous, $\mathrm{P}(\mathrm{mg} / \mathrm{dl})$ & $4.84 \pm 0.194$ & $4.43 \pm 0.254$ & $0.166^{\mathrm{NS}}$ \\
\hline Magnesium, $\mathrm{Mg}(\mathrm{mg} / \mathrm{dl})$ & $2.06 \pm 0.074$ & $2.00 \pm 0.024$ & $0.488^{\mathrm{NS}}$ \\
\hline Total Protein, $\mathrm{TP}(\mathrm{g} / \mathrm{dl})$ & $8.65 \pm 0.105$ & $8.21 \pm 0.112$ & $0.036^{*}$ \\
\hline Bilirubin $(\mathrm{mg} / \mathrm{dl})$ & $0.739 \pm 0.034$ & $0.707 \pm 0.042$ & $0.607^{\mathrm{NS}}$ \\
\hline
\end{tabular}

$\mathrm{P}=$ probability; $\mathrm{n}=$ number of serum specimen; $\mathrm{NS}=$ not significant $(P>0.05) ; *^{*}=$ significant at $5 \%$ level $(P<0.05)$.

\section{Discussion}

Repeat breeding is one the most common reproductive disorders which hinders favorable productivity in dairy animals (Ayalon 1984). To aid in ameliorating repeat breeding problem, comparative evaluation of serum concentrations of calcium $(\mathrm{Ca})$, phosphorus $(\mathrm{P})$, magnesium $(\mathrm{Mg})$, total protein $(\mathrm{TP})$ and bilirubin in normal cyclic (NC) and repeat breeder (RB) cows had been performed in the present studies before and after onset of estrus.

\subsection{Serum calcium concentration}

In this study, mean levels of serum calcium before onset of estrus and during standing estrus in RB cows were significantly lower than those of the NC cows. Our findings are in agreement with those of Akhtar et al. (2014) and Amle et al. (2014). However, lower level of calcium in NC cows and higher level of calcium in RB cows had also been reported (Chandrahar and Tiwari, 2003). This difference might be attributed towards different breeds or plain of nutrition provided to the animals. Among macro minerals, calcium is known to influence the animal's ability to use other trace minerals. Its influence on certain enzyme systems may be mediated via disruption of reproductive efficiency (Barui and Batabyal, 2015). Calcium plays a key role in improving the number and size of ovarian pre-ovulatory follicles, and the ovulation rate (El-Shahat, 2010). Synthesis of ovarian steroids is under the control of gonadotropic hormone regulation in which the calcium plays a pivotal role (Carnegie and Tsang, 1984). It was also reported that regulation of the membrane potential of oocytes is controlled by the calcium (Amle et al., 2014). Decreased serum calcium level in RB cows could sensitize reproductive organs through various hormones and thus, is an indication for repeat problem in cows (Moodie, 1965). 


\subsection{Serum phosphorus concentration}

In this study, serum phosphorous levels in RB cows were significantly lower than those of NC cows in both phases of estrus cycle (before starting estrus and during standing estrus). These findings are in conformity with those of other investigations (Modi et al., 2013; Akhter et al., 2014; Amle et al., 2014; Kumar et al., 2014), while not agreed with that of Barui et al. (2015). Phosphorus is essential for transfer of biological energy (ATP) and its deficiency may arrest the phenomenon of fertilization, and may cause early embryonic death resulting in the repeat breeding and anoestrum condition (Sharad and Atul, 2010). However, it was found that both deficiency and excess of phosphorous can cause impaired fertility in cattle (Lotthammer 1983). Inorganic phosphorus also facilitates sperm motility. Thus, lower inorganic phosphorus in repeat breeder cows might cause conception failure by hindering sperm motility and affecting respiration adversely.

\subsection{Serum magnesium concentration}

In this study, serum magnesium level in NC cows was found significantly higher than those in RB cows both during onset of estrus. These findings are in agreement with those of Akhter et al (2014). Lowered magnesium level in RB buffaloes have also been reported (Das et al., 2009). However, serum magnesium levels in both NC and RB cows between two phases of estrus cycle (before and after estrus) did not differ significantly $(P>0.05)$. Thus, it may be speculated that estrus cycle does not have any triggering effect on serum magnesium level in cows. Therefore, low levels of serum magnesium found in RB cows during onset of estrus might have relationship with repeat breeding problem.

\subsection{Serum total protein concentration}

In this study, there was no significant difference between $\mathrm{NC}$ and $\mathrm{RB}$ crossbred cows with respect to the levels of total serum protein either before onset of estrus or during estrus. Our findings are different from those of others who found discrepant protein levels between NC and RB cows during different stages of reproductive life (Amle et al., 2014; Kumar et al., 2014). In the present study, serum total protein concentrations in both NC and $\mathrm{RB}$ cows before standing estrus were significantly lower than those after standing estrus. This might be due to the fact that extra protein is utilized for the synthesis of gonadotropins and gonadal hormones as well as preparatory activities for estrus cycle (Arosh and Kathiresan, 1998). According to Arosh et al. (1998), low level of plasma protein resulted in the deficiency of certain amino acids required for the biosynthesis of gonadotropins and gonadal hormones. Lack of biosynthesis of gonadal hormones might cause discrepancy of reproductive hormones leading to dysfunction of ovaries in animals.

\subsection{Serum bilirubin concentration}

Before onset of estrus, serum bilirubin concentrations did not differ significantly between the NC and the RB cows. Our findings are in the line of those of Pariza et al. (2009). Also, bilirubin concentrations in NC cows differed significantly $(P<0.01)$ between two phases of estrus cycle. Bilirubin concentration decreased when cows came into estrus. However, in RB cows, bilirubin concentration did not vary significantly $(P>0.05)$ between two phases of estrus cycle. Though we are unable to interpret bilirubin data with repeat breeding problem at this phase, further studies could explore the related mechanism.

\section{Conclusions}

This study was conducted to investigate the serum biochemical profile which can provide supportive evidence about the importance of total protein, bilirubin and some macro minerals as calcium, inorganic phosphorus and magnesium in relation to repeat breeding incidence in dairy cows. Results of the present study identified that lower levels of calcium, inorganic phosphorus and magnesium might be associated with the ovulatory disturbances in repeat breeder cows. It can be inferred from this study that total protein and bilirubin are not involved in causing repeat breeding problem in the experimental cows. Finally, it may be concluded that farmers facing repeat breeding problems in their dairy cows should be concerned about the deficiency of macro minerals, especially calcium, phosphorus and magnesium. Feeds rich in calcium, phosphorus and magnesium should be provided to their cows or these minerals available in the market may be supplemented in dairy ration.

\section{Acknowledgements}

Authors are grateful to Jahangirnagar University and Bangladesh Livestock Research Institute for providing financial and instrumental support. 
Conflict of interest

None to declare.

\section{References}

Akhtar MS and A AsimFarooq, 2014. Studies on serum macro and micro minerals status in repeat breeder and normal cyclic Nili-Ravi buffaloes and their treatment strategies. Afr. J. Biotechnol., 13: 1143-1146.

Amle M and V Patodkar, 2014. Serum biochemical levels of repeat breeder cross bred cows under rural condition of Satara District of Maharashtra. Int. J. Adv. Vet. Sci. Technol., 3: 109-113.

Arosh AJ and D Kathiresan, 1998. Blood biochemical profile in normal cyclical and anoestrus cows. Ind. J. Anim. Sci., 68: 1154-1156.

Austin C, 1951. Observations on the penetration of the sperm into the mammalian egg. Austr. J. Biol. Sci., 4: 581-596.

Ayalon N, 1984. The repeat breeder problem. 10th international congress on animal reproduction and artificial insemination, University of Illinois at Urbana-Champaign (USA), 10-14 Jun 1984, University of Illinois at Urbana-Champaign, USA.

Baghel R, 2006. Reproductive disorders in relation to malnutrition in dairy animals. XXII Annual Convention of ISSAR and National Symposium.

Barui A and S Batabyal, 2015. Plasma mineral profiles and hormonal activities of normal cycling and repeat breeding crossbred cows: a comparative study. Vet. World, 8: 42-45.

Butcher FR, 1978. Regulation of exocytosis. Biochem. Act. Horm., 5: 53-99.

Carnegie J and B Tsang, 1984. The calcium-calmodulin system: participation in the regulation of steroidogenesis at different stages of granulosa cell differentiation. Biol. Reprod., 30: 515-522.

Chandrahar D and R Tiwari, 2003. Serum biochemical profile of repeat breeder cows. Indian J. Anim. Reprod., 24: 125-127.

Conn PM and JG Chafouleas, 1981. Gonadotropin releasing hormone stimulates calmodulin redistribution in rat pituitary. Nature, 292: 264.

Das P and S Biswas, 2002. Micronutrient status of dairy cattle in new alluvial zone of West Bengal. Ind. J. Anim. Sci., 72: 171-173.

Das JM, P Dutta, KC Deka, RK Biswas, BC Sarmah and A Dhali, 2009. Comparative study on serum macro and micro mineral profiles during oestrus in repeat breeding crossbred cattle with impaired and normal ovulation. Liv. Res. Rur. Dev., 21: 15-17.

Dhaliwal G, 2005. Managing dairy herds for optimal reproductive efficiency. Recent concepts in physiopathology of animal reproduction. Adv. Stud. Vet. Gynaecol. Reprod., 1-9.

Dutta J and Baruah, 1988. Blood biochemical studies in anestrous and normal cyclic cattle. Ind. Vet. J., 65: 239-241.

El-Shahat K, 2010. The effect of dietary supplementation with calcium salts of long chain fatty acids and/or 1carnitine on ovarian activity of Rahmani ewes. Anim. Reprod. Sci., 117: 78-82.

Ghosh AK and KL Maharjan, 2001. Impacts of dairy cooperative on rural income generation in Bangladesh. J. Intl. Dev. Co-op., 8: 91-105.

Lotthammer K, 1983. Comparative studies of the course of mineral, metabolite, enzyme and hormone levels in blood serum ante partum in dairy cows with and without later retained placenta. Deuts. Tier. Woch., 90: 427430.

Modi LC, BN Suthar, CF Chaudhari, NF Chaudhari, HC Nakhashi and F Modi, 2013. Trace minerals profile of blood serum and estrual mucus in repeat breeder Kankrej cows. Vet. World, 6: 143-146.

Moodie EW, 1965. Modern trends in animal health and husbandry: hypocalcaemia and hypomagnesaemia. Brit. Vet. J., 121: 338-349.

Pariza K, A Bari, F Bari, M Alam and M Noor, 2009. Clinico-pathological profiles of sub-fertility in Zebu Cows. Bangladesh Vet., 26: 1-7.

Saraswat CS and GN Purohit, 2016. Repeat breeding: Incidence, risk factors and diagnosis in buffaloes. Asi. Pac. J. Rep., 5: 87-95.

Sharad K and S Atul, 2010. Comparative studies on metabolic profile of anestrous and normal cyclic Murrah buffaloes. Buf. Bull, 29: 7-11. 